\title{
Immunohistochemical assessment of E-cadherin, $\beta$-catenin, CEACAM-1 and PTEN: tumor progression markers in melanoma
}

Primeira submissão em 12/08/09 Última submissão em 11/02/10 Aceito para publicação em 12/02/10 Publicado em 20/04/10

\section{Análise imuno-histoquímica dos marcadores de progressão tumoral, E-caderina, $\beta$-catenina, CEACAM-1 e PTEN em melanomas}

\begin{abstract}
Juliana Elizabeth Jung'; Raul Anselmi Júnior²; Lucas Gennaro3; Fernanda El Ghoz Leme; Ana Paula Camargo Martins ${ }^{5}$; Carlos G. Hirth ${ }^{6}$; Luiz Fernando Bleggi Torres ${ }^{7}$; Lúcia de Noronha ${ }^{8}$
\end{abstract}

\begin{abstract}
key words
Cutaneous melanoma

Immunohistochemistry

Cadherins

Beta-catenin

CEACAM-1

PTEN

abstract

Introduction and objective: The aim of the present study is the immunohistochemical assessment of tumor progression markers (E-cadherin, $\beta$-catenin, CEACAM- 1 and PTEN) in primary cutaneous melanomas and their correlation with prognostic factors. Method: Primary lesions in patients with cutaneous melanoma were recorded as to clinical data (age, gender, location and metastases) and anatomopathologic data (Breslow, Clark level, margins, histological type, mitosis, ulceration, regression, satellitosis and TIL type). It was made a comparison between immunohistochemical expression of the markers and prognostic and anatomopathologic factors. Results: Breslow thickness was $>1 \mathrm{~mm}$ (thick) in 21 patients (48.83\%) and $\leq 1 \mathrm{~mm}$ (thin) in $22(51.16 \%)$. There was a higher CEACAM-1 positive expression in thick melanomas than in thin ones $(p=0.002)$. There was a more frequent E-cadherin $(p=0.008), \beta$-catenin $(p=0.001)$ and PTEN $(p=0.005)$ positive expression in thin melanomas than in thick ones. There was a more frequent CEACAM-1 positive expression in superficial $(p=0.003)$ and deep $(p=0.002)$ samples of thick melanomas than in thin ones. No statistically significant differences between clinical and histopathological data were found when comparing patients with $(n=6)$ and without metastasis $(n=15)$. Discussion and conclusion: There was a higher positivity for E-cadherin, $\beta$-catenin and PTEN in thin melanomas, whereas there was a higher positivity for CEACAM-1 in thick melanomas.
\end{abstract}

resumo

Introdução e objetivo: O objetivo do presente estudo está na avaliação imuno-histoquímica de marcadores de progressão tumoral (E-caderina, $\beta$-catenina, CEACAM-1 e PTEN) em melanomas cutâneos primários e sua correlação com fatores prognósticos. Método: Lesões primárias de pacientes portadores de melanoma cutâneo foram tabuladas quanto a dados clínicos (idade, sexo, localização e metástases) e anatomopatológicos (Breslow, nível de Clark, margens, tipo histológico, mitoses, ulceração, regressão, satelitose e tipo de TIL). Foi realizada comparação da expressão imuno-histoquímica dos marcadores em estudo com fatores prognósticos clínicos e anatomopatológicos. Resultados: Breslow foi $>1 \mathrm{~mm}$ (espesso) em 21 pacientes (48,83\%) e $\leq 1 \mathrm{~mm}$ (fino) em 22 (51,16\%). CEACAM-1 foi mais positivo em melanomas grossos que em finos ( $p=0,002)$. E-caderina $(p=0,008), \beta$-catenina $(p=0,001)$ e PTEN $(p=0,005)$ foram mais frequentemente positivos em melanomas finos que em grossos. CEACAM-1 foi mais frequentemente positivo nas porções superficiais $(p=0,003) e$ profundas $(\mathrm{p}=0,002)$ dos melanomas grossos que nas dos finos. Não houve diferenças estatisticamente significativas entre dados clínicos e histopatológicos quando comparamos os pacientes com $(\mathrm{n}=6)$ e sem ( $\mathrm{n}=15$ ) metástases. Discussão e conclusão: Observou-se maior tendência de positividade para E-caderina, $\beta$-catenina e PTEN em melanomas finos. Por sua vez, CEACAM-1 demonstrou maior frequência de positividade nos melanomas grossos.

\section{unitermos}

Melanoma cutâneo

Imuno-histoquímica

Caderinas

Beta-catenina

CEACAM-1

PTEN

\footnotetext{
1. Doutoranda em Clínica Cirúrgica da Universidade Federal do Paraná (UFPR).

2. Doutorando em Microbiologia, Parasitologia e Patologia da UFPR.

3. Residente em Dermatologia pela UFPR.

4. Graduanda em Medicina pela UFPR; bolsista do Conselho Nacional de Desenvolvimento Científico e Tecnológico (CNPq).

5. Mestra em Ciência da Saúde; bióloga responsável pelo Laboratório de Patologia Experimental do Centro de Ciências Biológicas e da Saúde (CCBS) da Pontifícia Universidade Católica do Paraná (PUCPR).

6. Residente em Anatomia Patológica do Departamento de Patologia Médica da UFPR.

7. Doutor; professor titular do Departamento de Patologia Médica da UFPR.

8. Doutora; professora da Pós-graduação em Ciências da Saúde do CCBS da PUCPR.
} 


\section{Introduction}

Cutaneous melanoma is one of the most aggressive neoplasms; it is responsible for $75 \%$ of skin cancer deaths and its incidence is increasing, particularly among the white population ${ }^{(28)}$.

The aggressive nature and increasing incidence of this neoplasm together with the absence of an effective cure for disseminated melanoma, underline the importance of estimating the risk of progression of the disease and hence determining a prognosis for these patients, particularly at the time the diagnosis is made ${ }^{(11)}$.

While clinical and histological data about primary cutaneous melanomas provide useful prognostic information, the clinical course of this neoplasm may be unpredictable and additional factors are required to predict its evolution ${ }^{(18)}$.

Recently, advanced molecular biology techniques have made it possible to identify molecular markers, that are the subject of investigations aimed at establishing a correlation between their expression and current prognostic factors, survival rate and the risk of progression and metastasis in melanoma patients. The characterization of new proteins involved in the genesis, development and progression of melanomas helps to identify both patients who have a risk of a worse prognosis and potential therapeutic targets that might help in the treatment of these patients ${ }^{(9)}$.

The authors' hypothesis was therefore that the expressions of tumor progression markers, such as epithelial cadherin (E-cadherin), $\beta$-catenin, carcinoembryonic antigen-related cell adhesion molecule 1 (CEACAM-1) and phosphatase and tensin homologue deleted on chromosome 10 (PTEN) could help predict the prognosis for these tumors. In other words, the hypothesis was based on the fact that there might be a correlation between these biomarkers and the aggressiveness of primary cutaneous melanoma.

Cadherins are calcium-dependent transmembrane glycoproteins that mediate cell-cell adhesion. E-cadherin is involved in the melanocyte-keratinocyte interaction ${ }^{(24)}$. Loss of E-cadherin expression has been related to progression and metastasis of cutaneous melanoma ${ }^{(19)}$.

The protein $\beta$-catenin links E-cadherin to the cytoskeleton, playing an important role in cellular adhesion ${ }^{(15)}$. It has been described that the loss of $\beta$-catenin expression was associated with an aggressive behavior of melanoma and it contributed to progression of the disease ${ }^{(3,13)}$.
CEACAM-1 is a cell adhesion molecule, whose expression in primary cutaneous melanoma has been associated with subsequent development of metastasis ${ }^{(2)}$.

The tumor suppressor gene PTEN has been shown to play an important role in the pathogenesis of a variety of human cancers and it has been proposed that PTEN is involved in melanoma tumorigenesis and might also play a role in melanoma progression ${ }^{(29,30)}$.

The aim of the present study was to assess the expression of tumor progression markers E-cadherin, $\beta$-catenin, CEACAM- 1 and PTEN in surgical specimens of primary cutaneous melanomas using immunohistochemical techniques on tissue microarrays and determine the correlation between this expression and the current histopathological and clinical prognostic factors of this tumor.

\section{Materials and methods}

The lesions studied were from patients of both sexes and all age groups who had primary cutaneous melanoma and had been operated on between 1997 and 2005 in the Surgical Oncology Unit at the Hospital Nossa Senhora das Graças, Curitiba, Paraná. Exclusion factors were a prior incisional biopsy, insufficient sample size and in situ melanoma.

The clinical variables evaluated were age, sex, location of the lesion and presence or not of metastasis (nodal or systemic). For the patients which information about the clinical follow-up was available, it was at least of 2 years. The histopathological variables were the Breslow index, Clark level, mitotic count per 10 high power fields (HPFs), ulceration, histological regression, satellitosis and tumor-infiltrating lymphocytes (TIL). Melanomas were considered thick if Breslow index was over $1 \mathrm{~mm}$ and they were considered thin if Breslow index was equal to $1 \mathrm{~mm}$ or less. The patients were divided into those with thick and those with thin tumors. TILs were classified as brisk or nonbrisk. The markers used were mouse primary monoclonal antibodies against E-cadherin, $\beta$-catenin, CEACAM-1 and PTEN.

Immunohistochemical analysis was carried out after histological slides had been prepared by the tissue microarray (TMA) technique. Three TMAs were prepared, of which two were from specimens from thick melanomas - one superficial specimen, close to the epidermis, and one deep specimen, from a deeper portion of the tumor in the dermis - and one from specimens from thin melanomas. The following primary antibodies (Novocastra T, Newcastle 
upon Tyne, UK) and specifications (class and dilution) were used: E-cadherin - immunoglobulin G $1(\lg G 1)$, diluted 1:100; $\beta$-catenin - immunoglobulin $\mathrm{G} 2 \mathrm{a}$ ( $\operatorname{lgG} 2 \mathrm{a}$ ), diluted 1:800; CEACAM-1 - IgG 1 kappa, diluted 1:200; and PTEN - IgG 1 kappa, diluted 1:200.

Expression was assessed by the global positivity of the samples (number of samples with positive reactions) and the distribution pattern of the positive samples (diffuse or focal for positive reactions).

Immunohistochemical reactions were considered either positive, when there was characteristic staining, or negative. The characteristic staining for E-cadherin, $\beta$-catenin and CEACAM - 1 was cytoplasmatic staining. For PTEN, nuclear and/or cytoplasmatic staining was considered positive.

The distribution pattern of the positive samples consisted of the following categories: diffuse, when the reaction extended over more than $25 \%$ of the assessable sample and focal, when it extended over less than 25\%.

Statistical analysis was carried out using Student t test, Mann-Whitney $U$ test, Pearson chi-square test and Fisher exact test ( $p$ value statistically significant difference with $p<0.05$ ).

This study was approved by the ethic committees at the Pontifical Catholic University of Paraná and Hospital Nossa Senhora das Graças.

\section{Results}

Fourty-three cases of primary cutaneous melanoma were divided into thick melanomas: 21 patients (48.83\%); and thin melanomas: 22 patients (51.16\%).

The results of the clinical and histopathological variables for thin and thick melanomas, as well as a comparison between the two groups, are shown in Table $\mathbf{1}$.

In the group of patients with thick melanomas, followup was available in eight patients and metastasis (nodal or systemic) was present in four (50\%). In 13 cases, follow-up was not available.

In the group of patients with thin melanomas, follow-up was available in 13 patients and metastasis was present in two (15.3\%). In nine cases, follow-up was not available.

Median Breslow index $(p<0.001)$, presence of ulceration $(p=0.02)$ and mitotic count per $10 \mathrm{HPFs}$ $(p=0.04)$ were higher in thick melanomas.

The results for the immunohistochemical variables in thick and thin melanomas are shown in Tables $\mathbf{2}$ and $\mathbf{3}$.
The immunohistochemical assessment from each marker is illustrated in Figures 1 to 4.

When we compared immunohistochemical results for global positivity in terms of thin and thick melanomas, we observed that positive CEACAM-1 tests were more frequent in thick melanomas than in thin ones $(p=0.002)$. However, when we compared immunohistochemical results for global positivity in terms of thin cases and deep or superficial portions of thick melanomas, we observed that: a) positive E-cadherin $(p=0.008), \beta$-catenin $(p=0.001)$ and PTEN $(p=0.005)$ tests were more frequent in thin melanomas than superficial sample of thick ones; b) positive CEACAM-1 tests were more frequent in superficial $(p=0.003)$ and deep $(p=0.002)$ sample of thick melanomas than thin cases; and c) positive $\beta$-catenin tests $(p=0.03)$ were more frequent in deep sample of thick melanomas than in superficial portions.

When we compared immunohistochemical results for diffuse pattern in terms of thin cases and deep or superficial portions of thick melanomas, we observed that: a) the diffuse pattern of E-cadherin $(p=0.001)$ and CEACAM-1 $(p$ $=0.01$ ) were more frequent in the thin cases than in the superficial samples of thick melanomas, and were more frequent also ( $p=0.02$ and 0.005 respectively), in the deep samples of thick melanomas than superficial portions; b) the diffuse pattern of E-cadherin $(p=0.01)$ also were more frequent in the thin melanomas than deep portions of thick cases.

When we compared immunohistochemical results for focal pattern in terms of thin cases and deep or superficial portions of thick ones, we observed that the focal pattern of CEACAM-1 was more frequent in the superficial sample of thick melanomas than the deep portions $(p=0.01)$.

When we compared patients with $(n=6)$ and without metastasis $(n=15)$, in terms of clinical and histopathological data, no statistically significant differences was observed in the present study with either gender, age, location of the primary lesion, Clark level, mitotic count per 10 HPFs, ulceration, regression, satellitosis or TILs type. The Breslow index was higher in the patients with metastasis (median $=2.50 \mathrm{~mm}$ ) than in the patients without metastasis ( median $=0.56 \mathrm{~mm}$ ) with a $p$ value $=0.03$.

When we compared patients with $(n=6)$ and without metastasis $(n=15)$, in terms of immunohistochemical data, no statistically significant differences was observed in this present study with either E-cadherin, $\beta$-catenin, CEACAM- 1 and PTEN. However, the diffuse pattern of E-cadherin in the thick melanomas (superficial portion) showed a tendency 


\section{Clinical and pathological correlation between primary thick and thin cutaneous melanomas}

Table 1

\begin{tabular}{|c|c|c|c|}
\hline & $\begin{array}{l}\text { Thick melanomas } \\
\qquad(n=21)\end{array}$ & $\begin{array}{l}\text { Thin melanomas } \\
\qquad(n=22)\end{array}$ & $\begin{array}{l}\text { Comparison between thick } \\
\text { and thin melanomas }\end{array}$ \\
\hline Male & $10(47.62 \%)$ & $12(54.55 \%)$ & \multirow{12}{*}{$\begin{array}{l}\text { No statistically } \\
\text { significant difference }\end{array}$} \\
\hline Female & $11(52.38 \%)$ & $10(45.45 \%)$ & \\
\hline Average age (years) & 63.05 & 61.36 & \\
\hline Average male age (years) & 65.66 & 61.60 & \\
\hline Average female age (years) & 60.70 & 61.11 & \\
\hline Located on the back & $3(14.29 \%)$ & $5(22.72 \%)$ & \\
\hline Located on the trunk & $5(23.81 \%)$ & $2(9.09 \%)$ & \\
\hline Located on the head & 4 (19.04\%) & $3(13.64 \%)$ & \\
\hline Located on the neck & $1(4.76 \%)$ & $2(9.09 \%)$ & \\
\hline Located on the upper limbs & $3(14.29 \%)$ & $2(9.09 \%)$ & \\
\hline Located on the lower limbs & $3(14.29 \%)$ & $5(22.72 \%)$ & \\
\hline Location not mentioned & $2(9.52 \%)$ & $3(13.64 \%)$ & \\
\hline Median Breslow index & $2 \mathrm{~mm}$ & $0.55 \mathrm{~mm}$ & $\begin{array}{l}\text { Significantly higher in thick } \\
\text { melanomas }(p<0.001)\end{array}$ \\
\hline Clark level II & $2(9.52 \%)$ & $14(63.64 \%)$ & \multirow{3}{*}{$\begin{array}{l}\text { Clark level II predominant in } \\
\text { thin melanomas and level IV } \\
\text { predominant in thick melanomas } \\
\qquad(p=0.1)\end{array}$} \\
\hline Clark level III & $10(47.61 \%)$ & $8(36.36 \%)$ & \\
\hline Clark level IV & $9(42.86 \%)$ & 0 & \\
\hline Mitotic count $<3$ mitoses in $10 \mathrm{HPFs}$ & $10(47.61 \%)$ & $20(90.91 \%)$ & \multirow{3}{*}{$\begin{array}{l}\text { Mitoses more frequent in thick } \\
\text { melanomas }(p=0.04)\end{array}$} \\
\hline $\begin{array}{l}\text { Mitotic count } \geq 3 \text { mitoses and } \leq 8 \text { in } \\
10 \text { HPFs }\end{array}$ & 7 (33.33\%) & $2(9.09 \%)$ & \\
\hline Mitotic count $>8$ mitoses in $10 \mathrm{HPFs}$ & $4(19.04 \%)$ & 0 & \\
\hline Presence of ulceration & $9(42.86 \%)$ & 0 & $\begin{array}{l}\text { Ulceration more frequent in } \\
\text { thick melanomas }(p=0.02)\end{array}$ \\
\hline Regression & 7 (33.33\%) & 7 (31.82\%) & \multirow{2}{*}{$\begin{array}{l}\text { No statistically significant } \\
\text { difference }\end{array}$} \\
\hline Presence of satellitosis & $1(4.76 \%)$ & 0 & \\
\hline Brisk TILs & $1(4.76 \%)$ & $9(40.91 \%)$ & \multirow{2}{*}{$\begin{array}{l}\text { Brisk TILs more frequent in thin } \\
\text { melanomas and nonbrisk more } \\
\text { frequent in thick melanomas } \\
\qquad(p=0.15)\end{array}$} \\
\hline Nonbrisk TILs & $20(95.24 \%)$ & $13(59.09 \%)$ & \\
\hline
\end{tabular}

HPF: high power fields; TIL: tumor-infiltrating lymphocytes; $\mathrm{p}$ value statistically significant difference with $\mathrm{p}<0.05$.

to be more frequent in the cases without metastasis ( $p$ $=0.09$ ). Also, the global positivity of PTEN in the thick melanomas (superficial portions) showed a tendency to be more frequent in the cases without metastasis $(p=0.06)$.

\section{Discussion}

The literature indicates that there is a greater incidence of both thick and thin melanomas in males. The 


\section{Positive immunohistochemical tests (global positivity) in superficial and deep samples of thick} Table 2 melanomas $(n=21)$ and in thin melanomas $(n=22)$ with samples comparation and $p$ value

\begin{tabular}{ccccc}
\hline Samples & E-cadherin & Beta-catenin & CEACAM-1 & PTEN \\
Thin & $22(100 \%)$ & $21(100 \%)$ & $13(61.9 \%)$ & $20(90.9 \%)$ \\
Thick & $15(78.94 \%)$ & $16(80 \%)$ & $19(100 \%)$ & $09(45 \%)$ \\
Superficial & $11(68.75 \%)$ & $09(47.36 \%)$ & $19(100 \%)$ & $09(45 \%)$ \\
Deep & $15(78.94 \%)$ & $16(80 \%)$ & $19(100 \%)$ & $09(52.94 \%)$ \\
Thin $\times$ thick & $p=1$ & $p=1$ & $p=0.002$ & $p=1$ \\
Thin $\times$ superficial & $p=0.008$ & $p<0.001$ & $p=0.003$ & $p=0.005$ \\
Thin $\times$ deep & $p=1$ & $p=1$ & $p=0.002$ & $p=1$ \\
Deep $\times$ superficial & $p=0.46$ & $p=0.03$ & $p=1$ & $p=0.89$ \\
\hline
\end{tabular}

CEACAM-1: carcinoembryonic antigen-related cell adhesion molecule 1; PTEN: phosphatase and tensin homologue deleted on chromosome 10; $\mathrm{p}$ value statistically significant difference with $\mathrm{p}<0.05$.

\section{Distribution pattern (diffuse or focal) for positive immunohistochemical tests (with $p$ value) in} superficial and deep samples of thick melanomas $(n=21)$ and in thin melanomas $(n=22)$ with

Table 3 samples comparation and $p$ value

\begin{tabular}{cccccc}
\hline Samples & $\begin{array}{c}\text { Distribution } \\
\text { pattern }\end{array}$ & E-cadherin & Beta-catenin & CEACAM- 1 & PTEN \\
Thin & Diffuse & $22(100 \%)$ & $19(90.47 \%)$ & $10(76.92 \%)$ & $17(85 \%)$ \\
Superficial & & $07(63.63 \%)$ & $08(88.88 \%)$ & $09(47.36 \%)$ & $9(100 \%)$ \\
Deep & & $12(79.99 \%)$ & $14(87.5 \%)$ & $17(89.47 \%)$ & $7(77.77 \%)$ \\
Thin $\times$ superficial & Diffuse $p$ value & $<0.001$ & 1 & 0.01 & 1 \\
Thin $\times$ deep & & 0.01 & 1 & 1 & 1 \\
Deep $\times$ superficial & & 0.02 & 1 & 0.005 & 0.26 \\
Thin & Focal & 0 & $2(9.52 \%)$ & $3(23.07 \%)$ & $03(15 \%)$ \\
Superficial & & $4(36.36 \%)$ & $1(11.11 \%)$ & $10(52.63 \%)$ & 0 \\
Deep & & $3(20 \%)$ & $2(12.5 \%)$ & $02(10.52 \%)$ & $2(22.22 \%)$ \\
Thin $\times$ superficial & Focal $p$ value & 0.008 & 1 & 1 & 1 \\
Thin $\times$ deep & & 1 & 1 & 1 & 1 \\
Deep $\times$ superficial & & 0.25 & 1 & 0.01 & 0.02 \\
\hline
\end{tabular}

CEACAM-1: carcinoembryonic antigen-related cell adhesion molecule 1; PTEN: phosphatase and tensin homologue deleted on chromosome 10; $\mathrm{p}$ value statistically significant difference with $\mathrm{p}<0.05$.

area most affected in men is the trunk and in women is the leg, and the incidence of this neoplasm peaks in the sixth decade of life ${ }^{(14)}$. However, no statistically significant relationship was observed in the present study with gender, patient age or location of the primary lesion. Metastasis were more frequent in thick melanomas, which is in agreement with the literature, that considers the Breslow index to be the most important prognostic factor in cutaneous melanoma ${ }^{(5)}$. Analysis of the Clark level shows that levels II and IV were most frequently found in thin and thick melanomas, respectively, besides no statistically significant differences. This result is in agreement with those of Balch et al., who found that $84 \%$ of thin melanomas are level II or III and that less than $1 \%$ is level IV(4). The results for the mitotic count per $10 \mathrm{HPFs}$ agrees with the literature, as the mitotic frequency in the present study was greater in thick melanomas than in thin ones $(p=0.04)^{(7,14)}$. Ulceration was considerably more 
frequent in thick melanomas than in thin ones $(p=0.02)$, a finding that also agrees with the literature, according to which the incidence of ulceration increases with tumor thickness ${ }^{(4)}$. Lastly, brisk TILs were more frequent in thin melanomas and nonbrisk TILs more frequent in thick ones, besides no statistically significant differences, corroborating the data in the literature ${ }^{(8)}$.

Positive immunohistochemical results (global positivity) with CEACAM-1 were more frequent in thick melanomas than in thin ones $(p=0.002)$, even if we compare superficial $(p=0.003)$ and deep $(p=0.002)$ portions with thin cases. However, the diffuse pattern of CEACAM-1 was found more frequent in thin melanomas than in the superficial portions of thick ones $(p=0.01)$ and was found more frequent in the positive deep portions of "thick" cases than superficial ones $(p=0.005)$. We conclude that the expression of CEACAM-1 is stronger in the invasive edges of the tumor, in its deeper portions. As other studies have already shown, this adhesion molecule may play a role in the migration and invasion of melanoma cells and, consequently, may indicate bad prognosis. Thus, increased CEACAM-1 expression appears to be related to a greater incidence of metastases. In multivariate analyses correlating tumor thickness with other histopathological prognostic parameters, it has been suggested that positivity for CEACAM-1 is an independent risk factor for metastasis ${ }^{(6,25)}$. In this study, the increasing of global positivity of CEACAM- 1 correlated with increasing of thickness of melanoma cases, but not with the presence of metastasis.

With regard to the immunohistochemical profile of E-cadherin, the global positivity for this adhesion molecule was found more frequent in thin melanomas than in the superficial portion of thick ones $(p=0.008)$, but not when we compared the thin ones with deep portions of thick ones $(p=1)$ or, even if, we compared the thin ones with thick cases $(p=1)$. Eventually, the diffuse pattern of E-cadherin was found more frequent in thin melanomas than in the superficial $(p<0.001)$ or deep $(p=0.01)$ portions of thick ones. However, the diffuse pattern of E-cadherin was found more frequent in the deep portions of thick melanomas than the superficial ones $(p=0.02)$. These results are unexpected, since the literature indicates that there is an inverse relationship between E-cadherin expression and tumor thickness and that its high expression may have relationship with good prognosis $(2,13,17,22)$. However, previous studies of this biomarker showed that its expression is heterogeneous in cutaneous melanomas and that loss of E-cadherin expression is not a universal characteristic or indicator of tumor progression ${ }^{(13,21)}$. We believe that the
E-cadehrin expressed in edge of the tumors may be nonfunctioning and others studies already indicated that the fact that this molecule is being expressed does not mean that it is operating normally, and it should also be born in mind, that melanomas express new cadherins and that functionally altered neoplastic melanocytic cells may produce a factor that induces E-cadherin expression ${ }^{(16,19,23)}$. In this study, the increasing of positivity of E-cadherin correlated with decrease of the Breslow index of melanoma cases. Besides that, the diffuse pattern of E-cadherin has shown a slightly tendency to be more frequent in the cases without metastasis $(p=0.09)$ and good prognosis.

Beta-catenin global positivity was found to be greater in thin melanomas than in the superficial portion of thick ones $(p<0.001)$. Besides that, a statistically significant difference in global positivity in superficial and deep portions of thick melanomas was observed $(p=0.03)$, with the increasing of global positivity correlating with the increasing thickness. In the present study, only cytoplasmic staining of $\beta$-catenin was evaluated. The analysis of cytoplasmic versus membranous staining, as reported by others authors ${ }^{(27)}$ was not performed in our study and none of our specimens showed nuclear staining, as previously reported(3).

These last findings disagree with the majority of articles reviewed by the authors, which describe a reduction in $\beta$-catenin expression as tumor thickness increases and that suggest that the loss of this adhesion molecule plays a role in tumor progression ${ }^{(3,15)}$. This difference in expression and the conflicting results could be explained by various factors, such as tumor heterogenicity itself, differences in the way specimens are prepared (different fixation times) and the fact that antibodies are sourced from different laboratories.

As with E-cadherin and $\beta$-catenin, the frequency of fields positive for PTEN was higher in thin melanomas than in the superficial portion of thick ones $(p=0.005)$. These data agree with the literature, which relates increased tumor thickness to reduced PTEN expression and bad prognosis. Other studies also suggest that the reduction in the expression of this marker, that plays a role in apoptosis mechanism, is a late event and therefore relate it to the progression of the neoplasm ${ }^{(10,26,29)}$. In this study, the decrease of global positivity of PTEN correlated with the increasing of thickness of melanomas. Besides that, the global positivity of PTEN in the thick melanomas has shown slight tendency to be more frequent in the cases without metastasis $(p=0.06)$ and good prognosis.

The tissue microarray technique has been already used to evaluate molecular markers in cutaneous melanoma, and 
it has already been demonstrated that this technique allows the evaluation of innumerous samples simultaneously $(1,12,20)$. But it is important to emphasize that, in our study, the use of this technique could also be considered a limitation factor, since only one sample of tumor was used for each TMA. This may explain conflicting results, because only a small portion of tumors were analyzed and the heterogeneity of melanoma is very well known.

\section{Conclusion}

The increasing of global positivity of CEACAM-1 correlated with increasing of thickness of melanoma cases, but not with the presence of metastasis.
The increasing of positivity of E-cadherin correlated with decrease of the Breslow index of melanoma cases. Besides that, the diffuse pattern of E-cadherin has shown a slightly tendency to be more frequent in the cases without metastasis and good prognosis.

Beta-catenin global positivity was found to be greater in thin melanomas than in the superficial portion of thick ones. Besides that, a statistically significant difference in global positivity in superficial and deep portions of thick melanomas was observed, with the increasing of global positivity correlating with the increasing thickness.

The decrease of global positivity of PTEN correlated with the increasing of thickness of melanomas. Besides that, the global positivity of PTEN in the thick melanomas has shown slight tendency to be more frequent in the cases without metastasis and good prognosis.

\section{References}

1. ALONSO, S. R. et al. Progression in cutaneous malignant melanoma is associated with distinct expression profiles: a tissue microarray-based study. Am J Pathol, n. 164, p. 193-203, 2004

2. ANDERSEN, K. et al. Expression of S100A4 combined with reduced $\mathrm{E}$-cadherin expression predicts patient outcome in malignant melanoma. Mod Pathol, v. 17, p. 990-7, 2004.

3. BACHMANN, I. M. et al. Importance of P-cadherin, beta-catenin and Wnt5a/frizzled for progression of melanocytic tumors and prognosis in cutaneous melanoma. Clin Cancer Res, v. 11, p. 8606-14, 2005.

4. BALCH, C. M. et al. Prognostic factors analysis of 17.600 melanoma patients: validation of the American Joint Committee on Cancer melanoma staging system. J Clin Oncol, v. 19, p. 3622-34, 2001.

5. BRESLOW, A. Prognosis in cutaneous melanoma: tumor thickness as a guide to treatment. Pathol Annu, v. 15, p. 1-22, 1980.

6. BRÜMMER, J. et al. Cis interaction of the cell adhesion molecule CEACAM1 with integrin beta(3). Am J Pathol, v. 159, p. 537-46, 2001.

7. CLARK Jr, W. H. et al. Model predicting survival in stage I melanoma based on tumor progression. J Natl Cancer Inst, v. 81, p. 1893-904, 1989.

8. CLEMENTE, C. G. et al. Prognostic value of tumor infiltrating lymphocytes in the vertical growth phase of primary cutaneous melanoma. Cancer, v. 77, p. 1303-10, 1996.

9. FIGUEIREDO, L. C. et al. Skin cancer: main molecular markers of cutaneous melanoma. Rev Bras Cancerol, v. 3, p. 179- 83, 2003.

10. GOEL, V. K. et al. Examination of mutation in BRAF, NRAS and PTEN in primary cutaneous melanoma. J Invest Dermatol, v. 126, p. 154-60, 2006.
11. HOMSI, J. et al. Cutaneous melanoma: prognostic factors. Cancer Control, v. 12, p. 223-9, 2005.

12. KIELHORN, E. et al. Tissue microarray-based analysis shows phosfo- $\beta$-catenin expression in malignant melanoma is associated with poor outcome. Int $J$ Cancer, n. 103, p. 652-6, 2003.

13. KRENGEL, S. Cadherin expression pattern in melanocytic tumors more likely depends on the melanocyte environment than on tumor cell progression. J Cutan Pathol, v. 31, p. 1-7, 2004.

14. LeBOIT, P. E. et al. Pathology and genetics of tumour of the skin. World Health Organization Classification of Tumours. Lyon, France: IARC Press, 2006.

15. MAELANDSMO, G. M. et al. Reduced beta-catenin expression in the cytoplasm of advanced-stage superficial spreading malignant melanoma. Clin Cancer Res, v. 9, p. 3383-8, 2003.

16. MATSUYOSHI, N. et al. Identification of novel cadherins expressed in humam melanoma cells. J Invest Dermatol, v. 108, p. 908-13, 1997.

17. PECINA-SLAUS, N. et al. E-cadherin and beta-catenin expression patterns in malignant melanoma assessed by image analysis. J Cutan Pathol, v. 34, p. 239-46, 2007.

18. RICANIADIS, N. et al. Long-term prognostic significance of HSP-70, c-myc and HLA-DR expression in patients with malignant melanoma. Eur J Surg Oncol, v. 27, p. 88-93, 2001.

19. RUITER, D. J. et al. Markers of melanocytic tumour progression. J Pathol, v. 186, p. 340-2, 1998.

20. SÁ, B. C. et al. Expressão de fatores de proliferação e apoptose celular em melanomas cutâneos extensivos superficiais. Boletim Informativo do Grupo Brasileiro de Melanoma, n. 35, p. 4, 2006. 
21. SANDERS, D. S. et al. Alterations in cadherin and catenin expression during the biological progression of melanocitic tumors. Mol Pathol, v. 52, p. 151-7, 1999.

22. SILYE, R. et al. E-cadherin/catenin complex in benign and malignant melanocytic lesions. J Pathol, v. 186, p. 350-5, 1998.

23. STEINBERG, M. S. et al. Experimental specification of cell sorting, tissue spreading, and specific spatial patterning by quantitative differences in cadherin expression. Proc Natl Acad Sci USA, v. 91, p. 206-9, 1994.

24. TANG, A. et al. E-cadherin is the major mediator of human melanocyte adhesion to keratinocytes in vitro. J Cell Science, n. 107, p. 983-92, 1994.

25. THIES, A. et al. CEACAM1 expression in cutaneous malignant melanoma predicts the development of metastatic disease. J Clin Oncol, v. 20, p. 2530-6, 2002.
26. TSAO, H. et al. PTEN expression in normal skin, acquired melanocytic nevi, and cutaneous melanoma. J Am Acad Dermatol, v. 49, p. 865-72, 2003.

27. TUCCI, M. G. et al. Involvement of E-cadherin, betacatenin, Cdc42 and CXCR4 in the progression and prognosis of cutaneous melanoma. Br J Dermatol, v. 157, n. 6, p. 1212-6, 2007.

28. WEINLICH, G. et al. Metallothionein-overexpression as a prognostic factor for progression and survival in melanoma. A prospective study on 520 patients. Br J Dermatol, v. 149, p. 535-41, 2003.

29. WHITEMAN, D. C. et al. Nuclear PTEN expression and clinicopathologic features in a population-based series of primary cutaneous melanoma. Int J Cancer, v. 99, p. 63-7, 2002.

30. ZHOU, X. P. et al. Epigenetic PTEN silencing in malignant melanomas without PTEN mutation. Am J Pathol, v. 157, n. 4, p. 1123-8, 2000. 